\title{
Meningkatkan Penyesuaian Diri Terhadap Lingkungan Sekolah Melalui Layanan Bimbingan Klasikal Pada Siswa Kelas 7A SMP N 7 Muaro Jambi Tahun Pelajaran 2019-2020
}

\author{
Parida Ariati \\ Guru Bimbingan Dan Konseling SMPN 7 Muaro Jambi Kabupaten Muaro Jambi \\ Correspondence email: ariatiparida@gmail.com
}

\begin{abstract}
Abstrak. Penyesuaian diri di sekolah adalah suatu usaha atau proses yang dilakukan oleh seorang individu atau siswa dalam keadaan di lingkungan sekolah yang baru dikenalnya yang bertujuan untuk mencapai suatu hubungan yang harmonis antara lingkungan sekolah yang baru dengan individu tersebut untuk mencapai hasil belajar yang optimal. Bimbingan klasikal diberikan di kelas dengan materi yang dipersiapkan melalui RPL Bimbingan dan Konseling serta memperhatikan aktivitas agar terjadi interaksi yang membimbing antara guru BK dengan peserta didik dan proses belajar antar konseli. Tujuan bimbingan klasikal adalah membantu konseli agar mampu menyesuaikan diri, mampu mengambil keputusan untuk hidupnya sendiri, mampu beradaptasi dalam kelompok, mampu menerima support atau dapat memberikan support pada teman-temannya. Layanan bimbingan klasikal dapat digunakan sebagai salah satu upaya dalam meningkatkan penyesuaian diri siswa terhadap lingkungan sekolah. Penyesuaian diri siswa sebelum responden memperoleh perlakuan berupa bimbingan klasikal diperoleh kriteria rendah $(25 \%)$. Setelah mendapatkan bimbingan klasikal, kriteria rendah berkurang $(19 \%)$ pada siklus I kemudian $(0 \%)$ pada siklus 2. Pada kategori tinggi dari (3\%) meningkat menjadi (34\%) dengan demikian, terjadi peningkatan sebesar $31 \%$. Peningkatan tersebut meliputi aspek penyesuaian diri secara positif dan penyesuaian diri secara negatif. Sehingga dapat disimpulkan bahwa layanan bimbingan klasikal mampu meningkatkan penyesuaian diri siswa terhadap lingkungan sekolah. Penyesuaian diri siswa terhadap lingkungan sekolah menunjukkan peningkatan yang cukup signifikan setelah memperoleh layanan bimbingan klasikal yang berarti bimbingan klasikal dapat meningkatkan penyesuian diri terhadap lingkungan sekolah. Berdasarkan hasil penelitian melalui layanan bimbingan klasikal pada siswa kelas VII A SMPN 7 Muaro Jambi tahun pelajaran 2019/2020 terjadi peningkatan penyesuaian diri terhadap lingkungan sekolah melalui layanan bimbingan klasikal.
\end{abstract}

Kata kunci: Layanan Bimbingan Klasikal, Penyesuaian Diri Terhadap Lingkungan.

\begin{abstract}
Adaptation in school is an effort or process carried out by an individual or student in a new school environment that he or she is familiar with which aims to achieve a harmonious relationship between the new school environment and the individual to achieve optimal learning outcomes. Classical guidance is given in class with material prepared through Guidance and Counseling RPL and pays attention to activities so that there is a guiding interaction between BK teachers and students and the learning process between counselees. The purpose of classical guidance is to help counselees to be able to adapt, be able to make decisions for their own lives, be able to adapt in groups, be able to receive support or be able to provide support to their friends. Classical guidance services can be used as an effort to improve students' adjustment to the school environment. Students' selfadjustment before the respondent received treatment in the form of classical guidance obtained low criteria (25\%). After receiving classical guidance, the low criteria decreased (19\%) in the first cycle and then ( $0 \%)$ in the second cycle. In the high category from $(3 \%)$ increased to (34\%) thus, there was an increase of $31 \%$. The increase includes aspects of positive adjustment and negative adjustment. So, it can be concluded that classical guidance services are able to improve students' adjustment to the school environment. Students' adjustment to the school environment showed a significant increase after receiving classical guidance services, which means that classical guidance can increase their adjustment to the school environment. Based on the results of research through classical guidance services for class VII A students of SMPN 7 Muaro Jambi in the 2019/2020 school year, there was an increase in adjustment to the school environment through classical guidance services
\end{abstract}

Keywords: Classical Guidance Services, Adjustment to the Environment.

\section{PENDAHULUAN}

Dalam proses penyesuaian diri, individu dapat dikatakan berhasil apabila mampu memenuhi kebutuhan-kebutuhan dalam lingkungan dengan bertindak secara wajar yang ditandai oleh sikap tidak adanya rasa benci, mampu bertindak obyektif sesuai dengan kondisi dirinya,serta terhindar dari kegoncangan emosi, dan ketidakpuasan terhadap nasib yang dialami, sebaliknya individu yang gagal dalam melakukan penyesuaian diri atau disebut penyesuaian diri yang salah akan ditandai dengan berbagai tingkah laku yang salah, tidak terarah, emosional, sikap yang tidak realistik dan agresif.

Berdasarkan fakta lapangan melalui wawancara kepada sebagian siswa ada VII di SMP NEGERI 7 Muaro Jambi tidak dapat menyesuaikan diri antara lain terjadi permasalahan sosial dengan teman karena perbedaan, senang menyendiri, tidak mau memulai untuk berinteraksi, tidak mau menanggapi pendapat 
Parida Arianti, Meningkatkan Penyesuaian Diri Terhadap Lingkungan Sekolah Melalui Layanan Bimbingan Klasikal Pada Siswa Kelas 7A SMP N 7 Muaro Jambi Tahun Pelajaran 2019-2020

teman, siswa tidak bisa mengerti salah satu mata pelajaran karena guru yang bersangkutan sering tidak masuk, masih banyak yang berkelompok-kelompok kecil.

Makhluk sosial, manusia selalu mengadakan interaksi dengan lingkungan untuk memenuhi berbagai kebutuhannya. Individu selalu berusaha mencapai hubungan yang harmonis dengan lingkungannya. Manusia juga dituntut untuk mampu mengatasi segala masalah yang timbul sebagai akibat dari interaksi dengan lingkungan sosial dan harus mampu menampilkan diri sesuai dengan norma atau aturan yang berlaku.

Konseli sebagai individu yang dinamis dan berada dalam proses perkembangan memiliki kebutuhan dan dinamika dalam interaksinya dengan lingkungan. Manusia sebagai pribadi yang unik memiliki perbedaan karakteristik antara individu yang satu dengan individu yang lain. Saat konseli memasuki masa remaja, terkadang konseli mengalami berbagai masalah yang ada karena terjadi perubahan fisik, psikis, dan juga ligkungan sosial. Masa transisi ini sangat banyak menimbulkan kesulitan-kesulitan dalam penyesuaian dirinya terhadap lingkungan yang baru. Perkembangan remaja pada hakekatnya adalah usaha penyesuaian diri yaitu usaha secara aktif mengatasi tekanan-tekanan dan mencoba mencari jalan keluar dari berbagai masalah yang dihadapinya. Kemampuan individu mengatasi masalah yang ada tersebut tergantung dari bagaimana seorang remaja mempergunakan pengalaman yang diperoleh dari lingkungan dan selanjutnya kemampuan menyelesaikan masalah tersebut akan dapat membentuk sikap pribadi yang optimis dan dewasa.

Penyesuaian diri adalah suatu upaya yang dilakukan oleh seorang individu yang bertujuan untuk mengubah dirinya agar sesuai dengan lingkungan yang baru ditempatinya. "Penyesuaian diri merupakan proses bagaimana inidividu mencapai keseimbangan diri dlam memenuhi kebutuhan sesuai dengan lingkungan" (Sunarto \& Agung, 2002). Penyesuaian diri mempunyai peranan yang sangat penting dalam menentukan bagaiamana indvidu tersebut memperoleh keharmonisan baik secara jasmani ataupun rohani. Penyesuaian diri dalam prosesnya muncul berbagai hambatan atau masalah yaitu berupa konflik, tekanan, dan juga frustasi, dan dalam keadaan tersebut individu berusaha untuk mencoba berbagai perilaku agar dirinya tersebut dapat membebaskan diri dari masalah yang ada agar inidividu tersebut dapat meningkatkan kemampuan penyesuaian dirinya.

Penyesuaian diri menuntut kemampuan remaja untuk hidup dan bergaul secara wajar terhadap lingkungannya, sehingga remaja merasa puas terhadap dirinya dan juga terhadap lingkungannya. Remaja yang mengalami penyesuaian diri yang buruk, kehidupan kejiwaannya ditandai dengan kegoncangan emosi atau kecemasan yang menyertai rasa bersalah, cemas, merasa tidak puas dengan apa yang telah didapatkan, dan keluhan terhadap apa yang dialaminya. Jika seorang remaja tersebut berhasil dalam melakukan proses penyesuaian diri, maka remaja tersebut merasa aman, bahagia, memiliki sikap dan juga pandangan yang positif.

Dalam penelitian ini subjek penelitian dilakukan pada kelas VII dan kelas VIII, karena pada saat mencari informasi mengenai penyesuaian diri terhadap lingkungan sekolah, subjek masih duduk di kelas VII. Penelitian dan pemberian layanan bimbingan klasikal subjek penelitian kelas VII. diperoleh hasil bahwa, sebagian besar siswa kelas VII yang berjumlah 7 kelas, diketahui secara keseluruhan setiap kelas terdapat siswa yang penyesuaian dirinya kurang. Misalnya, di kelas VII B terdapat 4 siswa yang tingkat penyesuaian dirinya kurang. Fenomena tersebut didukung oleh wawancara peneliti dengan beberapa siswa kelas VII SMP N 2 Juwana yang mendapatkan hasil, bahwa beberapa siswa kurang begitu mengenal teman sekelasnya. Kemudian peneliti juga melakukan wawancara dengan siswa lain tentang guru yang baru, dan setelah beberapa wawancara dilakukan diketahui bahwa siswa tersebut kurang begitu menyukai guru yang baru tersebut karena cara mengajar yang kurang dapat diterima oleh mereka. Fenomena tersebut juga ditunjang oleh data yang diperoleh dalam bentuk media cetak yaitu hasil need asessment yang berupa sosiometri dan hasil analisis DCM, berdasarkan data tersebut dijelaskan bahwa permasalahan secara umum yang dialami siswa di sekolah adalah masalah pada bidang pribadi dan sosial. Sesuai dengan isu yang merebak diatas mengenai rendahnya tingkat penyesuaian diri siswa di lingkungan sekolah, apabila hal tersebut tidak segera ditangani kebutuhan siswa dalam bidang pribadi, belajar, sosial dan karir akan terhambat dan mengakibatkan kurang optimalnya hasil belajar, dikarenakan lingkungan sekolah juga sangat mempengaruhi proses belajar mengajar. Apabila seorang siswa mampu menyesuaikan diri dengan 
Parida Arianti, Meningkatkan Penyesuaian Diri Terhadap Lingkungan Sekolah Melalui Layanan Bimbingan Klasikal Pada Siswa Kelas 7A SMP N 7 Muaro Jambi Tahun Pelajaran 2019-2020

lingkungan sekolah yang baru, maka siswa tersebut kemungkinan besar mendapatkan hasil belajar yang memuaskan, dan juga sebaliknya.

Melihat fenomena yang terjadi pada siswa kelas VII SMP N 7 Muaro Jambi dapat menyebabkan proses kegiatan belajar mengajar terhambat dan prestasi belajar menurun. Guna meningkatkan penyesuaian diri terhadap lingkungan sekolah tersebut dapat digunakan beberapa cara yang efektif, salah satunya adalah layanan bimbingan klasikal karena dengan menggunakan layanan bimbingan

Layanan bimbingan klasikal dapat diasumsikan tepat dalam membantu meningkatkan penyesuaian diri. Melalui layanan bimbingan klasikal siswa yang tidak dapat menyesuaikan diri dan siswa yang mampu menyesuaikan diri dapat berkomunikasi atau berinteraksi dalam memecahkan suatu permasalahan antar anggota kelompok dan bersama-sama dengan menyatukan jawaban melalui pemikiran berbagai latar belakang yang mendasari pendapat siswa baik dari pengalaman, pengetahuan, bakat, serta ketrampilan berpikir yang dimunculkan dari rasa empati masing-masing anggota kelompok, serta dari munculnya gagasan atau ide-ide baru yang nantinya diharapkan dapat memberikan peningkatan siswa mengenai penyesuaian diri. layanan bimbingan ini mereka dapat berlatih perilaku baru, belajar menyesuaikan diri dengan yang lain, memberi dan menerima dan belajar memecahkan masalah berdasarkan masukan dari anggota yang lain.

\section{LANDASAN TEORI}

Manusia dalam kehidupan keseharian nya tidak akan pernah terbebas dari berbagai perasaan yang tidak menyenangkan. Penyesuaian diri adalah salah satu aspek penting dalam usaha manusia untuk menguasai perasaan yang tidak menyenangkan atau tekanan akibat dorongan kebutuhan, usaha memelihara keseimbangan antara pemenuhan kebutuhan dan tuntutan lingkungan dan usaha menyelaraskan hubungan individu dengan realitas.

Guru mempunya kedudukan peran sebagai profesional di jenjang pendidikan dasar, pendidikan menengah dan pendidikan pada usia dini. Sedangkan Guru Bimbingan dan Bonseling (BK) adalah seorang tenaga profesional yang memperoleh pendidikan khusus di perguruan tinggi dan mencurahkan seluruh waktunya pada layanan bimbingan. Guru BK ini memberikan layanan-layanan bimbingan kepada para siswa dan menjadi konsultan bagi staf sekolah dan orang tua (Winkel \& Sri Hastuti, 2012).

Penyesuaian diri ialah kemampuan seseorang untuk hidup dan bergaul secara wajar terhadap lingkungannya, sehingga ia merasa puas terhadap dirinya dan terhadap lingkungan (Sofyan S. Willis, 2008).

Pendidikan merupakan bagian terpenting dalam kehidupan sebagai faktor utama dalam pembentukkan pribadi manusia. Salah satu komponen dalam sistem pendidikan adalah peserta didik. Peserta didik merupakan pribadipribadi yang sedang berada dalam proses perkembangan. Dalam tahap perkembangannya siswa SMP digolongkan sebagai masa remaja pasca kanak-kanak. Hurlock (1999) memberi batasan masa remaja berdasarkan usia kronologis, yaitu antara tiga belas tahun hingga enam belas atau tujuh belas tahun. Masa remaja ditinjau dari rentang kehidupan manusia merupakan masa peralihan dari masa kanak-kanak menuju ke masa dewasa. Setiap individu mempunyai tugas-tugas perkembangan yang berbeda dalam fase kehidupannya. Menurut Hurlock (1999) salah satu tugas perkembangan masa remaja yang tersulit adalah yang berhubungan dengan penyesuaian sosial.

Penyesuaian diri merupakan "perbaikan perilaku yang dibangun oleh eseorang". Seseorang yang merasa kalau selama ini perilakunya menyebabkan dirinya sulit untuk menyatu dan diterima dalam kelompok, maka orang tersebut akan berusaha untuk memperbaiki perilakunya, sehingga dapat diterima oleh kelompok (Hurlock, 1994). Penyesuaian diri adalah "sebagai suatu proses ke arah hubungan yang harmonis antara tuntutan internal dan tuntutan eksternal" (Sunarto, 2002). "Penyesuaian diri merupakan suatu proses alamiah dan dinamis yang bertujuan mengubah perilaku individu agar terjadi hubungan yang lebih sesuai dengan kondisi lingkungannya" (Fatimah, 2006). "Tingkah laku manusia dapat dipandang sebagai reaksi terhadap berbagai tuntutan dan tekanan lingkungan tempat ia hidup, seperti cuaca dan berbagai unsur alamiah lainnya". Semua makhluk hidup secara alami telah dibekali kemampuan untuk menolong dirinya sendiri dengan cara menyesuaikan diri dengan keadaan lingkungan alam untuk dapat bertahan hidup (Carles Darwin dalam Fatimah, 2006). Jadi penyesuaian diri menurut peneliti adalah suatu usaha atau proses yang dilakukan oleh seorang individu dalam keadaan di lingkungan atau situasi yang baru 
Parida Arianti, Meningkatkan Penyesuaian Diri Terhadap Lingkungan Sekolah Melalui Layanan Bimbingan Klasikal Pada Siswa Kelas 7A SMP N 7 Muaro Jambi Tahun Pelajaran 2019-2020

dikenalnya yang bertujuan untuk mencapai suatu hubungan yang harmonis antara lingkungan yang baru dengan individu tersebut.

Kategori penyesuaian diri ada dua yaitu penyesuaian diri secara positif dan penyesuaian diri secara negatif (Sunarto, 2002)

Penyesuaian Diri secara PositifMereka yang tergolong mampu melakukan penyesuaian diri secara positif ditandai hal-hal sebagai berikut: (1) tidak menunjukkan adanya ketegangan emosional yaitu apabila ketika individu mampu menghadapi suatu masalah yang dihadapi mampu menghadapi dengan tenang dan tidak menunjukkan ketegangan, misalnya tenang, ramah, senang, dan tidak mudah tersinggung, (2) tidak menunujukkan adanya frustasi pribadi yaitu individu tidak menunjukkan perasaan cemas dan tegang pada situasi tertentu atau situasi yang baru, misalnya percaya diri dan tidak mudah putus asa, (3) memiliki pertimbangan rasional dan pengarahan diri yaitu individu mampu menunjukkan atau memiliki pilihan yang tepat dan logis, individu mampu menempatkan dan memposisikan diri sesuai dengan norma yang berlaku, misalnya mempertimbangkan dahulu apa yang akan dilakukan dan berhati-hati dalam memutuskan sesuatu, (4) mampu dalam belajar yaitu individu dapat mengikuti pelajaran yang ada di sekolah, dan dapat memahami apa yang diperoleh dari hasil belajar, misalnya senagn terhadap pelajaran dan berusaha menyelesaikan tugas yang diberikan oleh guru, (5) menghargai pengalaman yaitu individu mampu belajar dari pengalaman sebelumnya, dan individu dapat selektif dalam bersikap apabila menerima pengalaman yang baik atau yang buruk, misalnya belajar dari pengalaman dan tidak melakukan kesalahan yang sama, (6) bersikap realistik dan objektif yaitu individu dapat bersikap sesuai dengan kenyataan yang ada di lingkungan sekitarnya, tidak membedak-bedakan antara satu dengan yang lainnya, dan bertindak sesuai aturan yang berlaku.

\section{METODE PENELITIAN}

Subjek penelitian adalah peserta didik dari kelas 7a SMPN 7 Muaro Jambi, subjek dipilih adalah peserta didik yang baru memasuki orientasi sekolah baru. Objek penelitian ini adalah peningkatan penyesuaian diri terhadap lingkungan sekolah melalui layanan bimbingan klasikal. Topik bimbingan yang dipilih oleh peneliti adalah berdasarkan perilaku nyata terhadap motivasi belajar rendah yang di ungkap oleh subjek peneliti yaitu kurang memiliki keberanian untuk bertanya, cenderung pasif dan tidak memiliki keberanian dan tidak ada ketertarikan untuk belajar. Kemungkinan terjadi karena belum menyesuaikan diri terhadap lingkungan baru sehingga mempengaruhi motivasi belajar. Gejala-gejala tersebut sangat bertentangan dengan ciri-ciri siswa yang memiliki motivasi belajar yang tinggi seperti: (1) Senang belajar, (2) ingin mendalami materi yang dipelajari, (3) memiliki semangat untuk berprestasi, (4) menyadari pentingnya belajar, (5) memiliki ketekunan dalam belajar, (6) mempunyai cita-cita untuk belajar. Dalam upaya untuk meningkatkan motivasi dalam belajar melalui layanan bimbingan klasikal di susunlah topiktopik bimbingan dengan berkesinambungan.

Penelitian bimbingan kelas ini menggunakan model Kemmis \& Mc. Taggart dalam (Kusuma \& Dedi 2009) pelaksanaan model penelitian untuk terdiri dari empat komponen yaitu perencanaan, pelaksanaan, pengamatan, dan refleksi pada setiap tindakan dalam satu siklus

Pada Tahap pertama peneliti melakukan perencanaan yaitu merancang langkah-langkah yangkakan dilaksanakan sesuai dengan permasalahan dalam penelitian. Peneliti melakukan koordinasi dengan observer atau pengamat untuk menyusun program kegiatan serta jadwal pelaksanaantindakan. Penelitian menyiapkan alat dan bahan sesuai dengan perencanaan tindakan, menyusun instrument, wawancara, serta pedoman penilaian peserta didik. Tahap ini merupakan acuan dalam pemberian tindakan bimbingan.

Tahap kedua yaitu memberikan tindakan sesuai yang direncanakan, tahap ini memberikan layanan bimbingan klasikal dalam upaya peningkatan penyesuaian diri. Dalam 2 siklus dengan topik yang pertama adalah perencanaan karier masa depan pada siklus I dan topik kedua adalah berfikir dan bersikap positif pada siklus 2 .

Tahap ketiga adalah observasi atau pengamatan melalui observasi ini pengamat mengumpulkan informasi tentang kelebihan dan kelemahan terhadap tindakan yang dilakukan. Misalnya bagaimana peneliti 
Parida Arianti, Meningkatkan Penyesuaian Diri Terhadap Lingkungan Sekolah Melalui Layanan Bimbingan Klasikal Pada Siswa Kelas 7 A SMP N 7 Muaro Jambi Tahun Pelajaran 2019-2020

melakukan tindakan di kelas, situasi kelas, perilaku dan sikap yang ditunjukkan oleh siswa lain. Hasil obervasi dijadikan bahan untuk refleksi tindakan selanjutnya

Tahap keempat atau terakhir membuat refleksi terhadap tindakan yang sudah dilakukan hal apa yang menjadi kekuatan dan kelemahan dalam tindakan maka akan di refleksi. Selain itu dilihat juga hasil rrefleksi dari siswa sehingga dapat dipastikan apakah tindakan penelitian dapat bertujuan dengan baik dan semestinya. Jika tahap ini peneliti belum mendapat hasil yang sesuai dengan tujuan maka tidak menutup kemungkinan siklus tindakan akan berlanjut ke siklus berikutnya.

Teknik analisis data berupa angka dan non angka di analisis secara deskriptif disajikan secara virtual atau tabel yang menggambarkan adanya perubahan, perbaikan, ataupun kemajuan dibandingkan dengan keadaan sebelumnya, yaitu; 1) Analisis data angket motivasi belajar, 2) Analisis penilaian program untuk siswa dan 3) Data Observasi

\section{HASIL DAN PEMBAHASAN \\ Hasil}

Peneliti menyebarkan angket penyesuaian diri terhadap lingkungan sekolah kepada siswa sebelum memberikan layanan bimbingan guna mendapatkan data awal atau pra tindakan untuk mengetahui tingkat adaptasi lingkungan siswa. Dapat tergambar pada tabel berikut ini.

Tabel 1.

Jumlah Subjek dan Hasil Penyesuaian Diri Terhadap Lingkungan

Sekolah Pra Tindakan Melalui Bimbingan Klasikal

\begin{tabular}{|c|l|l|c|c|}
\hline No & $\begin{array}{l}\text { Rentang } \\
\text { Skor }\end{array}$ & Kategori & $\begin{array}{c}\text { Jumlah } \\
\text { Subjek }\end{array}$ & Persentase \\
\hline 1 & $\begin{array}{l}147,9< \\
\mathrm{X}\end{array}$ & $\begin{array}{l}\text { Sangat } \\
\text { tinggi }\end{array}$ & 0 & $0 \%$ \\
\hline 2 & $\begin{array}{l}123,3< \\
\mathrm{X} \\
<147,9\end{array}$ & Tinggi & 1 & $3 \%$ \\
\hline 3 & $\begin{array}{l}98,7<\mathrm{X} \\
<123,3\end{array}$ & Sedang & 23 & $72 \%$ \\
\hline 4 & $\begin{array}{l}74,1<\mathrm{X} \\
<98,7\end{array}$ & Rendah & 8 & $25 \%$ \\
\hline 5 & $<74,1$ & $\begin{array}{l}\text { Sangat } \\
\text { Rendah }\end{array}$ & 0 & $0 \%$ \\
\hline
\end{tabular}

Berdasarkan hasil analisis pada tabel di atas, terdapat $3 \%$ kategori tinggi, 72\% kategori sedang dan $25 \%$ kategori rendah. Guna melihat angket penyesuaian diri terhadap lingkungan sekolah secara keseluruhan agar kita dapat melihat sebatas mana penyesuaian diri terhadap lingkungan sekolah siswa tersebut sebelum di beri tindakan. Dan ini akan di jadikan tolak ukur pada saat setelah tindakan dilakukan apakah tindakan berhasil atau tidak. Hasil analisis ini dapat dilihat dari data dibawah ini.

\section{Gambar 1.}

Grafik Penyesuaian Diri Terhadap Lingkungan Sekolah Siswa Pra Tindakan

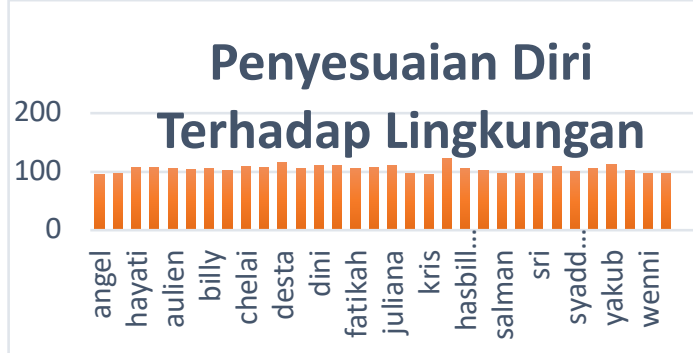




\section{Layanan Bimbingan Klasikal}

a. Teknik Pelaksanaan Bimbingan Siklus 1

Peneliti membagikan angket penyesuaian diri terhadap lingkungan sekolah di akhir tindakan. Tergambar pada tabel berikut ini.

Tabel 2.

Jumlah Subjek dan Hasil Penyesuaian Diri Terhadap Lingkungan Sekolah Siklus I Melalui Bimbingan Klasikal

\begin{tabular}{|c|l|l|c|c|}
\hline No & Rentang Skor & Kategori & $\begin{array}{c}\text { Jumlah } \\
\text { Subjek }\end{array}$ & Persentase \\
\hline 1 & $147,9<\mathrm{X}$ & $\begin{array}{l}\text { Sangat } \\
\text { tinggi }\end{array}$ & & $0 \%$ \\
\hline 2 & $\begin{array}{l}123,3<\mathrm{X} \\
<147,9\end{array}$ & Tinggi & 1 & $3 \%$ \\
\hline 3 & $\begin{array}{l}98,7<\mathrm{X}< \\
123,3\end{array}$ & Sedang & 25 & $78 \%$ \\
\hline 4 & $\begin{array}{l}74,1<\mathrm{X}< \\
98,7\end{array}$ & Rendah & 6 & $19 \%$ \\
\hline 5 & $<74,1<$ & $\begin{array}{l}\text { Sangat } \\
\text { Rendah }\end{array}$ & & $0 \%$ \\
\hline
\end{tabular}

Berdasarkan hasil analisis pada tabel di atas, terdapat $78 \%$ kategori sedang dan 3\% kategori tinggi dan masih ada kategori rendah yaitu 19\%. Guna melihat angket penyesuaian diri terhadap lingkungan sekolah secara keseluruhan agar kita dapat melihat sebatas mana penyesuaian diri terhadap lingkungan sekolah siswa tersebut setelah di beri tindakan. Dan ini akan di jadikan tolak ukur pada saat setelah tindakan dilakukan apakah tindakan berhasil atau tidak. Hasil analisis ini dapat dilihat dari data dibawah ini.

\section{Gambar 2.}

Grafik Penyesuaian Diri Terhadap Lingkungan Sekolah Siswa Siklus I

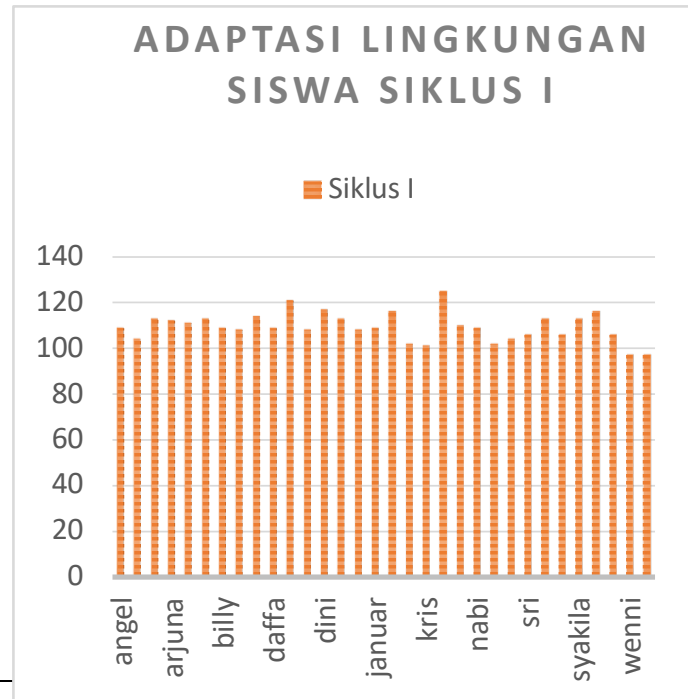




\section{b. Teknik Pelaksanaan Bimbingan Siklus 2}

Peneliti membagikan angket penyesuaian diri terhadap lingkungan sekolah di akhir tindakan. Tergambar pada tabel berikut ini.

Tabel 3.

Jumlah Subjek dan Hasil Penyesuaian Diri Terhadap Lingkungan Sekolah Siklus 2 Melalui Bimbingan Klasikal

\begin{tabular}{|c|l|l|c|c|}
\hline No & \multicolumn{1}{|c|}{$\begin{array}{c}\text { Rentang } \\
\text { Skor }\end{array}$} & Kategori & $\begin{array}{c}\text { Jumlah } \\
\text { Subjek }\end{array}$ & Persentase \\
\hline 1 & $147,9<\mathrm{X}$ & $\begin{array}{l}\text { Sangat } \\
\text { tinggi }\end{array}$ & & $0 \%$ \\
\hline 2 & $\begin{array}{l}123,3<\mathrm{X} \\
<147,9\end{array}$ & Tinggi & 11 & $34 \%$ \\
\hline 3 & $\begin{array}{l}98,7<\mathrm{X}< \\
123,3\end{array}$ & Sedang & 21 & $66 \%$ \\
\hline 4 & $\begin{array}{l}74,1<\mathrm{X}< \\
98,7\end{array}$ & Rendah & & $0 \%$ \\
\hline 5 & $<74,1$ & $\begin{array}{l}\text { Sangat } \\
\text { Rendah }\end{array}$ & & $0 \%$ \\
\hline
\end{tabular}

Berdasarkan hasil analisis pada tabel di atas, terdapat $66 \%$ kategori sedang dan 34\% kategori tinggi. Guna melihat angket penyesuaian diri terhadap lingkungan sekolah secara keseluruhan agar kita dapat melihat sebatas mana adaptasi lingkungan tersebut setelah di beri tindakan. Dan ini akan di jadikan tolak ukur pada saat setelah tindakan dilakukan apakah tindakan berhasil atau tidak. Hasil analisis ini dapat dilihat dari data dibawah ini.

\section{Gambar 3.}

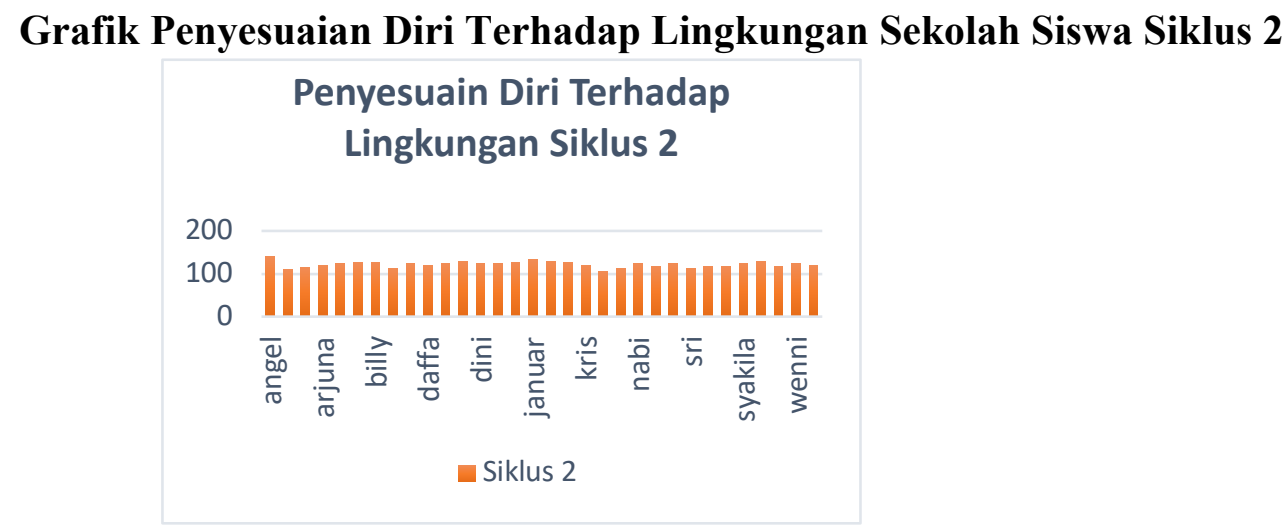

\section{Pembahasan}

Subjek berada pada kategori penyesuaian diri terhadap lingkungan sekolah setelah dilakukan tindakan baik itu dari siklus I dan II. Tergambar pada tabel berikut ini. 


\section{Tabel 4.}

Jumlah Subjek dan Hasil Persentase Tingkat Penyesuaian Diri Terhadap Lingkungan Sekolah Dari Pra Tindakan, Siklus I, Dan Siklus II

\begin{tabular}{|c|l|l|c|c|c|}
\hline No & $\begin{array}{c}\text { Rentang } \\
\text { Skor }\end{array}$ & Kategori & $\begin{array}{c}\text { Pra } \\
\text { Tindakan }\end{array}$ & $\begin{array}{c}\text { Siklus } \\
\text { I }\end{array}$ & $\begin{array}{c}\text { Siklus } \\
\text { II }\end{array}$ \\
\hline 1 & $147,9<\mathrm{X}$ & $\begin{array}{l}\text { Sangat } \\
\text { tinggi }\end{array}$ & $0 \%$ & $0 \%$ & $0 \%$ \\
\hline 2 & $\begin{array}{l}123,3<\mathrm{X} \\
<147,9\end{array}$ & Tinggi & $3 \%$ & $3 \%$ & $34 \%$ \\
\hline 3 & $\begin{array}{l}98,7<\mathrm{X} \\
<123,3\end{array}$ & Sedang & $72 \%$ & $78 \%$ & $66 \%$ \\
\hline 4 & $\begin{array}{l}74,1<\mathrm{X} \\
<98,7\end{array}$ & Rendah & $25 \%$ & $19 \%$ & $0 \%$ \\
\hline 5 & $<74,1$ & $\begin{array}{l}\text { Sangat } \\
\text { Rendah }\end{array}$ & $0 \%$ & $0 \%$ & $0 \%$ \\
\hline
\end{tabular}

Dapat Dilihat tingkat perkembangan peningkatan penyesuaian diri terhadap lingkungan sekolah dari tiap siklus terjadi peningkatan.

Sebelum dilakukan tindakan mayoritas kategori tinggi dalam penyesuaian diri terhadap lingkungan sekolah yaitu 3\% dengan kategori rendah yang tinggi yaitu $25 \%$ kemudian meningkat penyesuaian diri terhadap lingkungan sekolah pada siklus 1 yaitu 78\% kategori sedang, berkurangnya kategori rendah menjadi tersisia 19\%, pada siklus 2 terlihat kenaikan yang cukup signifikan yaitu 34\% kategori tinggi dan $0 \%$ kategori rendah. Dapat dilihat terjadi peningkatan penyesuaian diri terhadap lingkungan sekolah dengan layanan bimbingan klasikal.

Upaya peningkatan penyesuaian diri terhadap lingkungan sekolah yang mengalami perkembangan kearah yang lebih baik ini tidak begitu saja terjadi karena terdapat proses yang dilalui. Seperti di ungkap oleh Hurlock dalam Gunarsa (2004) menyatakan bahwa penyesuian diri adalah subjek yang mampu menyesuaikan diri kepada umum dan kelompoknya dan orang tersebut memperlihatkan perilaku yang menyenangkan, bearti orang tersebut diterima di lingkungan tersebut. penyesuaian diri terhadap lingkungan sekolah tidak dapat diamati secara langsung tetapi dapat diinterprestasikan dalam tindak laku berupa rangsangan, dorongan, dan pembangkit tenaga. Pada siswa kelas VII SMPN 7 Muaro Jambi yang belum memiliki kesadaran mengenai penyesuaian diri terhadap lingkungan sekolah menjadi salah satu pendukung dalam meningkatkan motivasi belajar.

Tindakan pada siklus 1 yang mendapat kategori penyesuaian diri terhadap lingkungan sekolah tinggi terdapat 3\% yaitu 1 orang dan kategori motivasi sedang $78 \%$ dan masih ada yang mendapat kategori rendah dibandingkan saat pra Tindakan yang kategori rendah cukup banyak. Hal tersebut menandakan bahwa siswa sudah meningkat penyesuaian diri terhadap lingkungan sekolah. penyesuaian diri terhadap lingkungan sekolah terjadi apabila ada kesadaran dan dorongan yang di terima oleh siswa dalam menerima pelajaran yang didapatkan baik dari keluarga, sekolah maupun lingkungan tempat tinggal sehingga siswa secara tidak langsung siswa melakukan perubahan tingkah laku yang lebih baik penyesuaian diri terhadap lingkungan sekolah yang nantinya berimbas ke meningkatnya motivasi belajar.

Pada Siklus 2 yang mendapat kategori penyesuaian diri terhadap lingkungan sekolah tinggi 34\% yaitu 11 orang dan kategori motivasi sedang 66\% yaitu 23 orang dan tidak ada lagi kategori rendah. penyesuaian diri terhadap lingkungan sekolah menjadi acuan terhadap tingginya motivasi siswa secara keseluruhan terjadi peningkatan.

\section{KESIMPULAN}

Berdasarkan hasil penelitian tentang meningkatkan penyesuaian diri terhadap lingkungan sekolah melalui layanan bimbingan klasikal pada siswa kelas VII A SMPN 7 Muaro Jambi tahun 2019/2020, dapat diketahui bahwa secara empiris ada peningkatan penyesuaian diri terhadap lingkungan sekolah, yang dijabarkan sebagai berikut: 
Parida Arianti, Meningkatkan Penyesuaian Diri Terhadap Lingkungan Sekolah Melalui Layanan Bimbingan Klasikal Pada Siswa Kelas 7 A SMP N 7 Muaro Jambi Tahun Pelajaran 2019-2020

1. Layanan bimbingan klasikal dapat digunakan sebagai salah satu upaya dalam meningkatkan penyesuaian diri siswa terhadap lingkungan sekolah.

2. Penyesuaian diri siswa sebelum responden memperoleh perlakuan berupa bimbingan klasikal diperoleh kriteria rendah (25\%). Setelah mendapatkan bimbingan klasikal, kriteria rendah berkurang $(19 \%)$ pada siklus I kemudian (0\%) pada siklus 2. Pada kategori tinggi dari (3\%) meningkat menjadi (34\%) dengan demikian, terjadi peningkatan sebesar 31\%. Peningkatan tersebut meliputi aspek penyesuaian diri secara positif dan penyesuaian diri secara negatif. Sehingga dapat disimpulkan bahwa layanan bimbingan klasikal mampu meningkatkan penyesuaian diri siswa terhadap lingkungan sekolah.

3. Penyesuaian diri siswa terhadap lingkungan sekolah menunjukkan peningkatan yang cukup signifikan setelah memperoleh layanan bimbingan klasikal yang berarti bimbingan klasikal dapat meningkatkan penyesuian diri terhadap lingkungan sekolah.

\section{DAFTAR PUSTAKA}

Ali, Muhammad dan Muhammad Asrori. (2005). Psikologi Remaja Perkembangan Peserta Didik. Jakarta: Bumi Aksara.

Al-Mighwar. (2006). Psikologi Remaja. Bandung: Pustaka Setia.

Belawati. (2003) Pengembangan Bahan Ajar, Jakarta, Pusat Penerbitan. Universitas Terbuka

Desmita. (2009). Psikologi Perkembangan Peserta Didik. Bandung: Remaja Rosda Karya

Fatimah, Enung. (2006). Psikologi Perkembangan (Perkembangan Peserta Didik). Bandung: Pustaka Setia.

Gerungan. (2004). Psikologi Sosial. Bandung: Refika Aditama.

Hartinah. (2010). Perkembangan Peserta Didik. Bandung: PT. Rafika. Aditama

Hadi. (2004). Metodologi Research. Yogyakarta: Andi Offset

Hidayat dan Badrujaman. (2012). Penelitian Tindakan dalam. Bimbingan Konseling. Jakarta: PT Indeks.

Hurlock, Elizabeth B. (1999). Perkembangan Anak. Jakarta: Erlangga.

Ketut Sukardi, Dewa. (2003). Manajemen Bimbingan dan Konseling di Sekolah. Bandung: Alfabeta.

Kusdiarti. (2010). Upaya Meningkatkan Kemampuan Penyesuaian Diri Remaja

Melalui Layanan Bimbingan Kelompok Pada Kelayan Panti Bina Remaja

Wira Adi Karya Ungaran. (2010). Skripsi. Program Sarjana Universitas Negeri Semarang.

Mappiare, Andi. (1982). Psikologi Remaja. Surabaya: Usana Offset.

Prayitno dan Erman Amti. (2004). Dasar-Dasar Bimbingan dan Konseling. Jakarta: Rineka Cipta.

Romlah, Tatiek. (2001). Teori dan Praktek Bimbingan Kelompok. Malang: Universitas Negeri Malang.

Satyaningsih, Indah. (2007). Upaya meningkatkan penyesuaian diri melalui layanan informasi bidang bimbingan sosial (penelitian pada siswa kelas XI SMA Negeri 10 Semarang tahun ajaran 2007/2008.

Skripsi. Program Sarjana Universitas Negeri Semarang.

Sofyan S, Willis. (1986). Problema Remaja dan Pemecahannya. Bandung: Angkasa.

Sugiono. (2005). Statistika Untuk Penelitian. Bandung: Alfabeta.

Sunarto dan Agung Hartono. 2002. Perkembangan Peserta Didik. Jakarta: Rineka Cipta.

Winkel dan Sri Hastuti. (2004). Bimbingan dan Konseling di Institusi Pendidikan. Yogyakarta: Media Abadi.

Wibowo, Mungin Eddy. (2005). Konseling Kelompok Perkembangan. Semarang: UPT UNNES Press.

Sugandi. (2008). Teori Pembelajaran. Semarang: UPT MKK UNNES

Sugiyono. (2011). Metode penelitian kuntitatif kualitatif dan R\&D. Alfabeta.

Sugiyono. (2012). Memahami Penelitian Kualitatif'. Bandung

Soetjipto dan Kosasi. (2000). Metodologi Penelitian Pendidikan, Jakarta: Rineka Cipta

Shertzer. dan Stone (1981). Fundamentals of Guidance. Boston: Houghton Mifflin

Romlah. (2006). Teori dan Praktek Bimbingan Kelompok. Malang

Kartono. (2002). Psikologi Umum. Bandung: Sinar Baru Algies Indonesia.

Yusuf dan Nurihsan. (2008). Landasan Bimbingan dan Konseling. Bandung: Remaja. 


\section{SIMPULAN}

Berdasarkan kepada permasalahan dan pertanyaan penelitian dan pembahasan yang telah dilakukan, maka dapat disimpulkan bahwa 1) Internal locus of control berpengaruh signifikan terhadap prestasi belajar mahasiswa pada Program Studi Pendidikan Ekonomi STKIP Nasional Padang Pariaman. Dimana ditunjukkan oleh nilai koefisien sebesar 0,000 Nilai koefisien ini signifikan karena nilai thitung $4.313>t_{\text {tabel }}$ sebesar 1.697. 2) Pemberian punishment berpengaruh signifikan terhadap prestasi belajar mahasiswa pada Program Studi Pendidikan Ekonomi STKIP Nasional Padang Pariaman. Dimana ditunjukkan oleh nilai koefisien sebesar 0,004. Nilai koefisien ini signifikan karena nilai thitung $3.127>t_{\text {tabel }} 1.697$. 3) Gaya belajar visual berpengaruh signifikan terhadap prestasi belajar mahasiswa Program Studi Pendidikan Ekonomi STKIP Nasional Padang Pariama. Dimana ditunjukkan oleh nilai koefisien sebesar 0,015. Nilai koefisien ini signifikan karena nilai $\mathrm{t}_{\text {hitung, }} 4,129>\mathrm{t}_{\text {tabel }}$ sebesar 1.697. 4) internal locus of control,pemberian punishment, dan gaya belajar visual berpengaruh signifikan terhadap prestasi belajar mahasiswa pada Program Studi Pendidikan Ekonomi STKIP Nasional Padang Pariaman, artinya semakin baik internal locus of control, pemberian punishment, dan gaya belajar visual, maka prestasi belajar mahasiswa juga akan semakin baik. Hal tersebut bisa dilihat dari nilai $F_{\text {hitung }} 104.999>F_{\text {tabel }} 2,43$ dan nilai signifikan 0,000 =0,05. Hal ini berarti $\mathrm{H}_{0}$ ditolak dan $\mathrm{H}_{a}$ diterima

Berdasarkan hasil penelitian dan kesimpulan yang telah penulis uraikan, maka untuk meningkatkan Prestasi belajar Mahasiswa Program Studi Pendidikan Ekonomi menjadi lebih baik untuk masa yang akan datang penulis menyarankan: 1) Untuk meningkatkan prestasi belajar mahasiswa ekonomi harus memperhatikan dan meningkatkan internal locus of control,pemberian punishment, kreatifitas belajar, dan gaya belajar visual, 2) Sebaiknya mahasiswa ekonomi meningkatkan internal locus of control karena dengan baiknya pengendalian diri seseorang idividu dan bekerja keras saat belajar, sehingga mendapatkan prestasi yang lebih baik lagi, 3) Buat dosen harus meningkatkan pemberian punisment kepada mahasiswa agar mahasiswa tersebut jera atau tidak maulagi untuk melanggar aturan yang telah dibuat. 4) Mahasiswa Program Studi Pendidikan Ekonomi agar memanfaatkan waktu dengan baik untuk menyelesaikan laporan atau tugas diperpustakaan dan menggumpulkan berbagai sumber bahan pelajaran untuk menambah kekurangan dari buku sumber. 5) Bagi peneliti selanjutnya dapat dijadikan rujukan dalam melakukan penelitian yang sejenis yang lebih mendalam di masa yang akan datang. 


\section{DAFTAR PUSTAKA}

Aliasar, M. (2008). Bahan Ajar Pedagogik. Padang: UNP.

Hamalik. (2010). Proses Belajar Mengajar. Bandung: Bumi Aksara.

Irawan. (2000). Logika dan Prosedur Penelitian. Jakarta: STIA-LAN.

Kreitne, R \& Kinichi. (2001). Organizational Behavior, Fith Edition International Edition, MC Grawu Hill Companies, Inc.

Kompri. (2015). Motivasi Pembelajaran. Bandung. PT Remaja Rosdakarya.

Kustini. (2005). Pengaruh Locus Of Control, Orintasi Tujuan Pembelajaran dan Lingkungan Kerja Terhadap Self Efficacy dan Tranfer Pelatihan Karywan PT, Telkom Kandetel Surabaya Timur. Studi Ilmu Penggembangan Sumber Daya Manusia, Thesis.Program Pasca Sarjana Universitas Ai.

Prasetya, F. D. (2012). Pengaruh Gaya Belajar Terhadap Prestasi Belajar Mata Diklat Listrik Otomotif Siswa Kelas XI Teknik Perbaikan Bodi Otomotif SMKN 2 Depok Sleman,.Jurnal. 1-208.

Robbins, P Stephen \& Timothy A Judge. (2008). Prilaku Organisasi. Jakarta: Salemba Empat.

Sardiman, AM. (2011). Interaksi dan Motivasi Belajar Mengajar. Jakarta: PT. Rineka Cipta.

Soemanto, Wasti. (2006). Psikologi Pendidikan. Jakarta: Rineka Cipta.

Sriwati. (2015). Kecerdasan Dan Gaya Belajar. Medan: Larispa Indonesia.

Sudjana. (2010). Dasar-Dasar Prosese Belajar Mengajar. Bandung: Rineka Cipta. 